\title{
FEASIBILITIES AND PERSPECTIVES FOR LANDFILL MINING IN LITHUANIA
}

\author{
Gintaras Denafas, \\ Algimantas Bučinskas \\ Department of Environmental Technology, Kaunas University of Technology, \\ Kaunas, \\ Lithuania
}

\begin{abstract}
Despite that mechanical-biological treatment and incineration as municipal waste treatment methods are already under starting positions, the landfilling leaves still a main MSW disposal method in Lithuania. Currently 11 modern regional landfills are exploited, and all in Lithuania acted district and township landfills and dumps have been closed and rehabilitated. The expected total amount of formerly landfilled recyclable fractions is about $645 \mathrm{Mt}$.

For EU funds closed and rehabilitated local landfills can not be in principle "touched". However the used and eventually almost already fullfilled regional MSW landfills have the additional inducement for restoration by landfill mining. Also the mining of special landfills for construction and demolition waste becomes already the practical character.
\end{abstract}

\section{KEYWORDS}

Exploited landfills, closed landfills, landfill mining, landfilled recyclable fractions

\section{Introduction: current situation with waste landfilling}

Average share of landfilled municipal solid waste (MSW) is 33 percent for European Union. Unfortunately, Lithuania belongs to the group of European countries where waste landfilling as waste disposal method remains predominant - about 79 percent of MSW are still landfilled (Fig. 1). [Municipal, 2014]. Recently, the share of MSW for recycling and energy generation increased considerably (Fig. 2) [Municipal, 2014]. This share could more still increased from 2013 after starting of Klaipeda waste incineration plant to be exploited by Finish company "Fortum energy". 


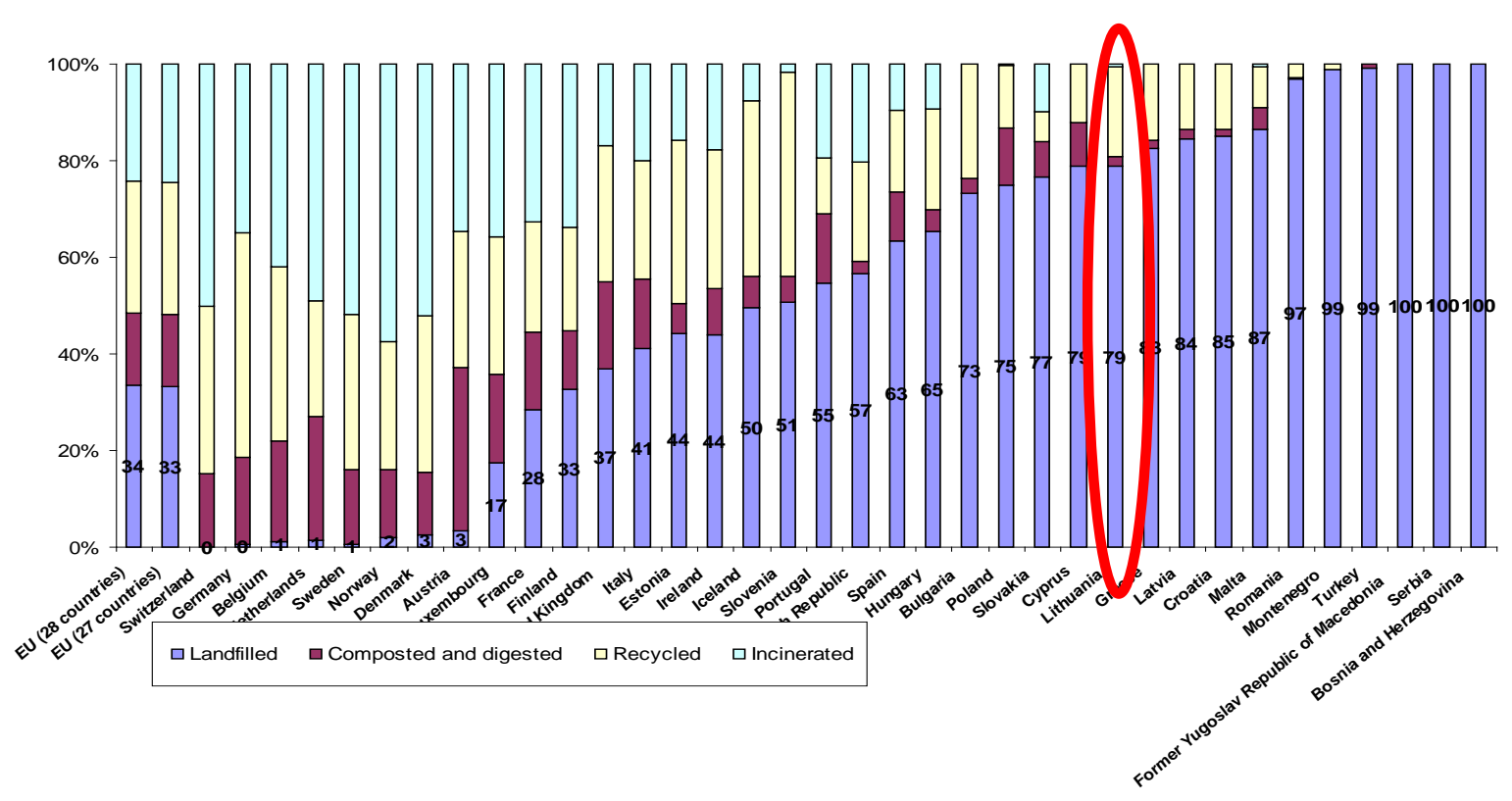

Figure 1: MSW landfilling and treatment rates in European countries, 2012

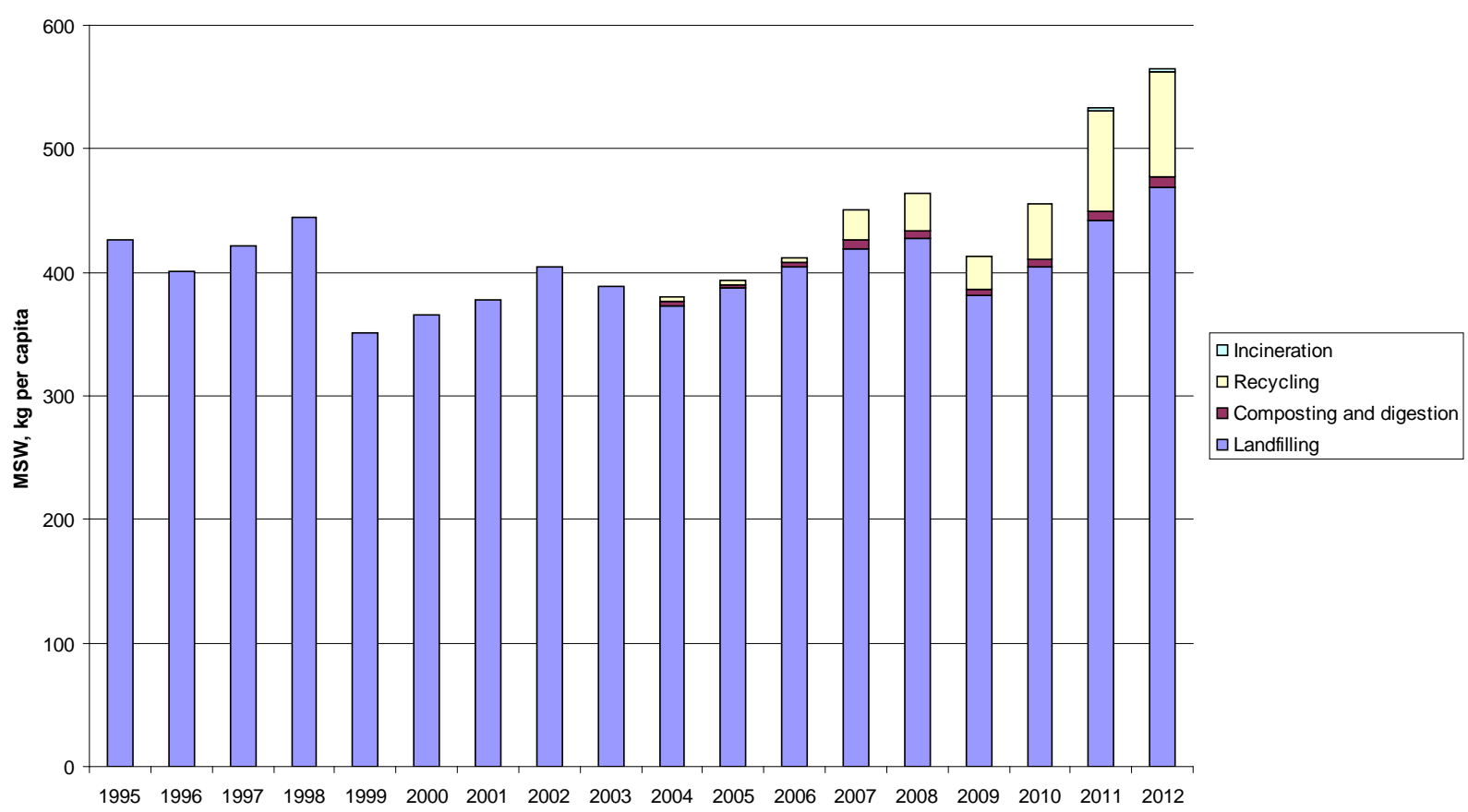

Figure 2: MSW generation and disposal in Lithuania, 1995-2012

According to the newest Lithuanian National Waste Management Plant MSW landfilling may be should remain a more symbolic during coming 15 years, because due to development of infrastructure for recycling, incineration and mechanical-biological treatment the landfilling 
of biodegradable and incinerable waste will be stopped till 2030 year [Valstybinis, 2014]. However the landfilling of MSW remains the main MSW disposal method at this time in Lithuania. Currently 11 modern regional landfills for MSW are exploited (Fig. 3).
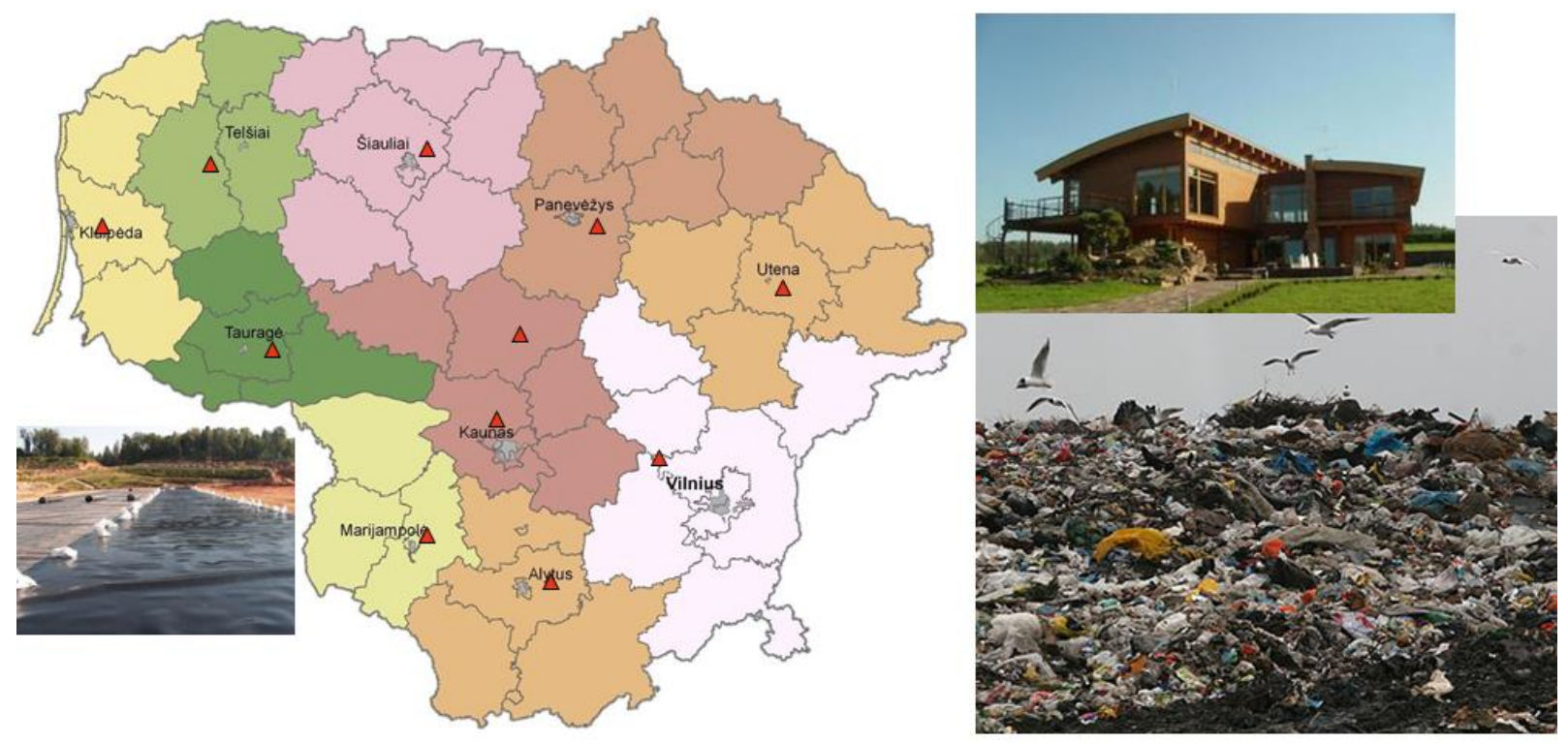

Figure 3: Locations of MSW regional landfills in Lithuania

Otherwise Lithuania counted up to 843 of closed landfills of different sizes, where during their operation time about 3.4 million tons of waste have been landfilled (apart the old Kariotiškès landfill, where municipal waste from Lithuanian capital city Vilnius was formerly disposed). Regarding the EU support many of these landfills have been already remediated (Fig. 4); the largest of which have installed landfill gas collection systems.

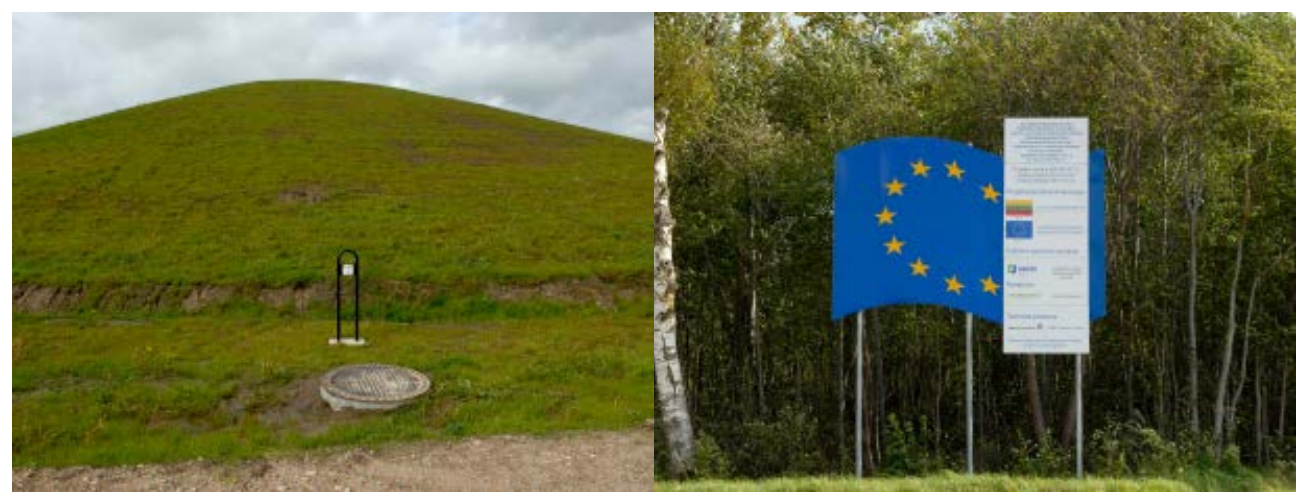

Figure 4: Example of rehabilitated landfill in Lithuania 


\section{Assumptions for landfill mining}

Currently the growing needs for remediation of old landfills and for recovering of resources are again the important drivers for the increased interest in landfill mining on the world. The former research and international cooperation project "Closing the Life Cycle of Landfills Landfill Mining in the Baltic Sea Region for Future” of Linnaeus University [Bhatnagar et al., 2013] was one of the most interesting European projects carried out on this topic. The project is a joint venture of research groups and institutes of the participating countries (Sweden, Latvia, Norway, Italy, Denmark, Estonia, Lithuania and Ukraine). Partnership in this project have emphasized the importance of the cross-sector cooperation among the experts from universities, waste management associations, municipalities and companies working towards achieving the goals established by Swedish Environment Protection Agency, HELCOM and the EU Waste Framework Directive. The main objective of this project was to initiate new full-scale landfill mining projects in the Baltic Sea Region and compare the obtained results with landfill mining projects in different countries. Therefore, the one of the results of this project is a slowly approaching investigation for landfill mining feasibilities in Lithuania.

Based on the data to be obtained from all Lithuanian regional waste management centers, the expected resources potential for closed landfills is presented in the Table 1. It was assumed that the content of disposed waste is similar like in excavated Kudjapi landfill (Saarema island, Estonia) during realisation of above mentioned project.

Table 1: Expected maximal resources potential in the closed Lithuanian landfills

\begin{tabular}{|c|c|c|c|c|c|c|}
\hline \multirow{3}{*}{$\begin{array}{l}\text { Waste } \\
\text { managemen } \\
\text { region }\end{array}$} & \multirow{3}{*}{$\begin{array}{l}\text { Number of } \\
\text { closed landfills }\end{array}$} & \multirow{3}{*}{$\begin{array}{l}\text { Amount of } \\
\text { disposed waste } \\
t\end{array}$} & \multicolumn{4}{|c|}{$\begin{array}{l}\text { Expected materials and energy potentials } \\
\text { according to Estonian model }\end{array}$} \\
\hline & & & \multirow{2}{*}{$\begin{array}{l}\text { Recyclable } \\
\text { plastics, } t\end{array}$} & \multirow{2}{*}{ Metals, $\mathbf{t}$} & \multicolumn{2}{|c|}{$\begin{array}{l}\text { Incinerable } \\
\text { materials, }\end{array}$} \\
\hline & & & & & $t$ & $T J$ \\
\hline Vilnius & 112 & 1545472 & 216369 & 77271 & 710915 & 6825 \\
\hline Kaunas & 98 & 219968 & 30796 & 10998 & 101185 & 971 \\
\hline Klaipèda & 51 & 157162 & 22003 & 7858 & 72295 & 694 \\
\hline Šiauliai & 157 & 165197 & 23128 & 8260 & 75991 & 730 \\
\hline Panevėžys & 95 & 875030 & 122504 & 43752 & 402514 & 3864 \\
\hline Alytus & 97 & 153000 & 21420 & 7650 & 70380 & 676 \\
\hline Marijampolé & 6 & 93240 & 13054 & 4662 & 42890 & 412 \\
\hline Telšiai & 55 & 212517 & 29752 & 10626 & 97758 & 938 \\
\hline Tauragé & 64 & 449500 & 62930 & 22475 & 206770 & 1985 \\
\hline Utena & 109 & 1026746 & 143744 & 51337 & 472303 & 4534 \\
\hline Total: & 844 & 4897832 & 475696 & 169892 & 1563003 & 15005 \\
\hline
\end{tabular}




\section{SWOT analysis for landfill mining}

\subsection{Strengths}

Earlier in Europe performed landfill mining projects (including the same mentioned Kudjapi project) have shown that this activity this activity have many strengths. The main environmental strengths are the geological stabilisation for the top of the landfill, landscape development and reduce of emissions for greenhouse gas and hazardous compounds. The economical strengths include during excavation the additional feasible potential of rawmaterials for energy and long life cycle products and in the "after care" period - feasibilities for other activities like sporting tracks or renewable energy sources (solar modules, wind power plants, energetic willow plantations). In turn, these two economical strengths lead to two additional economic strengths like reduce of monitoring costs for closed landfills and feasibilities for use of leachate for washing of recovered materials, social strength like enhanced employment and taxes and to additional environmental strength like reduce of indirect environmental impact to be caused by energetic and industrial facilities.

However for Lithuania not only these main typical strengths would be characteristic. MSW and RDF incineration in waste incineration plants and cement industry are still in Lithuanian under development, so landfill mining could cause the additional feasible energetic potential for these facilities. Also it could be an additional inducement for restoration of mentioned used and eventually almost already fullfilled regional MSW landfills. Finally it could be also the additional inducement for separate collection and recycling of MSW with corresponding decrease of landfilling in regional landfills and with enhance of landfilling requirements for 2030 year.

\subsection{Weaknesses}

The main weakness for LFM development in Lithuania is that mentioned small district and neighborhood landfills haven closed and rehabilitated for EU funds, therefore it can not be "touched" five years. Currently for Lithuanian waste managers and bureaucrats the LFM idea has yet low interest and even scepticism. Concerning economic aspects, landfill mining could be not feasible for particular period if landfill gas procuring would be cost-effective. Also the use of mined plastics could be restricted due to possible and unpredictable changes in the market.

If the process would be focused to recyclable plastics and RDF, the mining of disposed plastics could be not feasible for landfills which have been closed before increase of plastics content in the MSW. It could be feasible only for landfill layers which have been formed during the last 20 years.

For higher layers of currently exploited regional landfills the higher share of not decomposed biodegradable waste can be characteristic. Also the formerly performed wells show that from depth of $6 \mathrm{~m}$ the thick liquid mass is detected.

Finally the LFM activity will not have the long-term. The installation and exploitation of MBT and incineration facilities for MSW would reduce it in any case.

\subsection{Opportunities}

Despite started development of MBT and MSW incineration facilities in Lithuania and based on the properties of landfilled waste, the LFM activities can be prolonged, because closed 
district landfills can be mostly appropriate, the determined 5-year limitation does not preclude.

The increased separate collection and recycling, the mentioned MBT and incineration with significant reduce of waste landfilling can be make possible the LFM activities also for regional landfills after decrease of landfill gas procuring.

However the really current LFM activities in Lithuania are already performed in some dumps for construction and demolition waste (Fig. 4) [http://www.alfa.lt/straipsnis/12275169/vietoj-apleistu-fermu-zaliuos-pievos]. One of such activities with crushing of concrete waste belongs for JSC "Zarasu ST" on the area of closed construction and demolition waste dump near Visaginas city in Nord-East Lithuania.

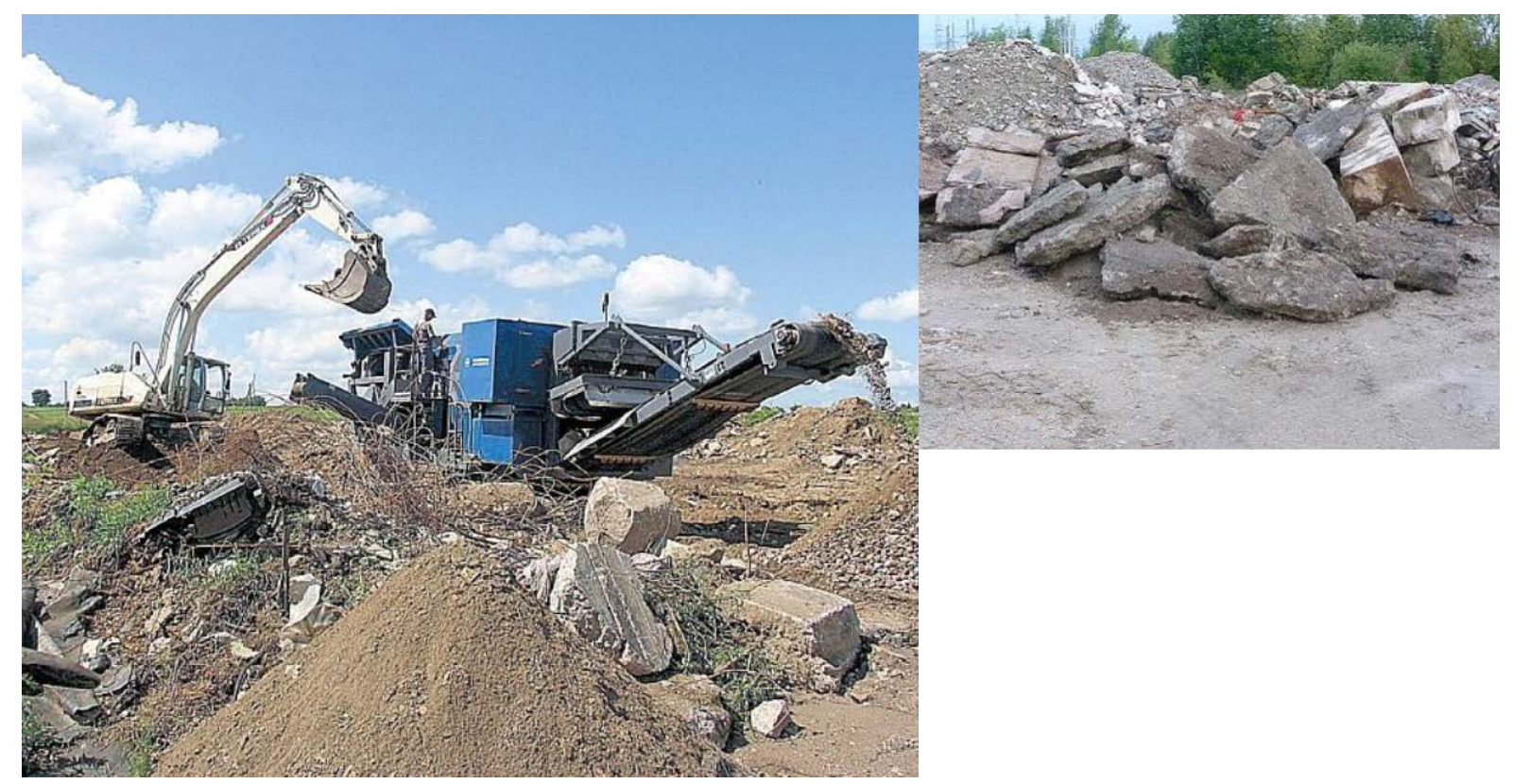

Figure 5: First LFM activities in Lithuania: recovering of raw materials for construction

\subsection{Threats}

There can be only one typical threat - the potential hazards due to geological instability of landfill tops and release of landfill gas and hazardous compounds during LFM activity.

\section{Summary and conclusions}

Recently, the trend for reduce of waste landfilling in Lithuania is increasingly noticeable. This is a good precondition for starting of long term landfill mining activities. Preliminary evaluation data show that about 170 thousand of metals, 475 thousand tons of plastics and about 1,5 million tons of potential recovered fuel can be accumulated in already closed and rehabilitated Lithuanian district landfills. However currently the landfill mining in such areas is restricted due to reason that these landfills have been closed and rehabilitated for EU funds, therefore it can not be "touched" five years. Therefore the mining of first fulfilled new 11 regional landfill sections can have a better perspective with respect to growing share of recycled, composted and incinerated waste. Currently only the mining of potential building materials from former dumps for construction and demolition waste is performed. 


\section{References}

Bhatnagar, A.; F. Kaczala, A.F.; Kriipsalu, M.; Hogland, M. and Hogland, W.

Closing the Life Cycle of Landfills - Landfill Mining in the Baltic Sea Region for Future. Proceedings Sardinia 2013, Fourteenth International Waste Management and Landfill Symposium S. Margherita di Pula, Cagliari, Italy; 30 September - 4 October 2013

Municipal waste generation and treatment, by type of treatment method. Source of Data: Eurostat. Last update: 04.09.2014. Date of extraction: 17 Sep 2014 14:41:48 MEST Hyperlink to the table:

http://epp.eurostat.ec.europa.eu/tgm/table.do?tab=table\&init=1\&plugin=1\&language=en\&pco $\mathrm{de}=\mathrm{tsdpc} 240$. General Disclaimer of the EC website:

http://ec.europa.eu/geninfo/legal_notices_en.htm

National Waste Management Plan. Government of Lithuanian Republic, 2014 (Lith.) -

Valstybinis atliekų tvarkymo planas. Lietuvos Respublikos vyriausybé, 2014 